Histidine at $1 \mathrm{~mm}$ had no effect on enzyme activity but at $10 \mathrm{~mm}$ it caused $50 \%$ increase in activity. At a concentration of $1 \mathrm{~mm}$ histidine reversed the inhibitory effect of iodine and $N$-bromosuccinimide. The effects of a variety of analogues of histidine on enzyme activity were also examined.

The authors express their gratitude to the Irish Committee for the International Biological Programme for a grant in support of this project.

Griffin, P. J. \& Fogarty, W. M. (1971a) J. Gen. Microbiol. 68, $\mathrm{xV}$

Griffin, P. J. \& Fogarty, W. M. (1971b) Biochem. J. $125,109 P$

Griffin, P. J. \& Fogarty, W. M. (1971c) Ir. J. Agr. Res. 10,2

Simpson, F. J. (1955) Can. J. Microbiol. 1, 131

\section{Polygalacturonate Lyase of a Bacillus sp. Associated with Increased Permeability of Sitka Spruce (Picea sitchensis)}

By O. P. WARD and W. M. FogarTY (Department of Industrial Microbiology, University College, Dublin 4, Irish Republic)

Water storage of Sitka spruce causes destruction of the tori and bordered pit membranes of the sapwood as a result of invasion by bacteria. Breakdown of the pits brings about an increase in permeability of the wood to preservatives. Since the pit membranes in sapwood contain considerable pectic material, pectinolytic enzymes may be important in degrading these structures (Ward \& Fogarty, 1971a). A Bacillus sp. isolated from stored Sitka spruce has been shown to produce high extracellular polygalacturonate lyase activity, even when glucose is used as sole carbon source (Ward \& Fogarty, 1971b). We have purified this enzyme and investigated some of its characteristics.

The cell-free supernatant of $48 \mathrm{~h}$ cultures grown on a glucose-basal salts medium was fractionated with $\left(\mathrm{NH}_{4}\right)_{2} \mathrm{SO}_{4}$. The $60-90 \%$-saturated-( $\left.\mathrm{NH}_{4}\right)_{2} \mathrm{SO}_{4}$ fraction was applied to a CM-cellulose column and the polygalacturonate lyase was eluted with $35 \mathrm{~mm}-$ phosphate buffer, pH6.5. This preparation was free of amylase, protease and xylanase activities. Further, the enzyme had a 59-fold increase in specific activity over the starting material.

The purified enzyme showed higher activity towards acid-soluble pectic acid (McReady \& Seegmiller, 1954) than it did towards sodium polygalacturonate, and the former was used as substrate in subsequent investigations. Addition of $\mathrm{Ca}^{2+}$ caused a fivefold increase in activity above the 'basal' value and $\mathrm{Sr}^{2+}$ had a slight activating effect. Most bivalent ions not only inhibited the 'basal' activity in the absence of added $\mathrm{Ca}^{2+}$, but also depressed the activating effect of $\mathrm{Ca}^{2+}$ on the enzyme. EDTA caused complete inhibition.

The purified enzyme appeared to be highly stable. At $30^{\circ} \mathrm{C}$ it retained $100 \%$ activity over the $\mathrm{pH}$ range 3.4-8.8 for $24 \mathrm{~h}$. It also retained full activity in deionized water at the same temperature for $24 \mathrm{~h}$. The enzyme showed considerable resistance to inactivation by a range of bacterial, animal and plant proteases.

Recent work has shown that polygalacturonate lyase activity is associated with increased permeability of Sitka spruce when stored in water (W. M. Fogarty \& O. P. Ward, unpublished work). Permeability increase is a relatively slow process (Dunleavy \& Fogarty, 1971) during which the pH falls from 7 to 5 . The stable nature of this polygalacturonate lyase must surely be highly advantageous to an enzyme involved in such a prolonged process.

This work was supported by a grant from the Forest and Wildlife Service of the Department of Lands, Dublin.

Dunleavy, J. A. \& Fogarty, W. M. (1971) Proc. Brit. Wood Preserving Assoc. 21st. Convention, Cambridge, 1-24

McCready, R. M. \& Seegmiller, C. G. (1954) Arch. Biochem. Biophys. 50, 440-450

Ward, O. P. \& Fogarty, W. M. (1971a) J. Gen. Microbiol. 68, xvi

Ward, O. P. \& Fogarty, W. M. (1971b) Biochem. J. 125, 109 P-110P

\section{The Structure of Secreted Proteins}

By D. H. LEABACK (Department of Biochemistry, Institute of Orthopaedics, Stanmore, Middlesex HA 7 4 LP, U.K.)

Fisher (1964), Bigelow (1967) and Gates \& Fisher (1971) have developed interesting approaches to the prediction of protein structure from a knowledge of the composition of individual proteins. A very simple model of the structure of globular proteins was adopted, consisting of a hydrophobic core surrounded by a shell of hydrophilic amino acid residues. On the basis of this model Bigelow (1967) showed that globular proteins had components with average hydrophobicities $\left(\mathrm{H} \phi_{\mathrm{av}}\right.$. $)$ close to $4.6 \mathrm{~kJ}(1.1 \mathrm{kcal}) / \mathrm{mol}$ of residue, and Fisher (1964) demonstrated that the hydrophobic core is inordinately diminished in small or asymmetric globular proteins.

Attached saccharides and disulphide bridges are structural features peculiar to secreted proteins (cf. Leaback, 1970). In order to assess, if possible, the properties conferred by these components on the structure of proteins, Fisher's (1964) 'polarity ratio' $(p)$, Bigelow's (1967) average hydrophobicity, and a new parameter $\chi$ termed the 'cross-link' index (defined 